\title{
Antioxidant Activities, Acute Toxicity and Chemical Profiling of Torch Ginger (Etlingera elatior Jack.) Inflorescent Extract
}

\author{
Bunleu Sungthong $^{1 *}$, Buavaroon Srichaikul ${ }^{2}$
}

\section{Bunleu Sungthong ${ }^{1 *}$, Buavaroon Srichaikul ${ }^{2}$}

\author{
'Pharmaceutical Chemistry and Natural \\ Product Research Unit, Faculty of \\ Pharmacy, Mahasarakham University, \\ Kantharawichai, Maha Sarakham \\ 44150, THAILAND. \\ ${ }^{2}$ Faculty of Public Health, \\ Mahasarakham University, \\ Kantharawichai, \\ Maha Sarakham 44150, THAILAND.
}

Correspondence

\section{Bunleu Sungthong}

Pharmaceutical Chemistry and Natural Product Research Unit, Faculty of Pharmacy, Mahasarakham University, Kantharawichai, Maha Sarakham 44150, THAILAND.

Phone no: +66 43754360

E-mail: bunleu.s@msu.ac.th

\section{History}

- Submission Date: 30-05-2018;

- Review completed: 28-06-2018;

- Accepted Date: 11-07-2018

DOI : 10.5530/pj.2018.5.166

\section{Article Available online}

http://www.phcogj.com/v10/i5

\section{Copyright}

(c) 2018 Phcog.Net. This is an openaccess article distributed under the terms of the Creative Commons Attribution 4.0 International license.

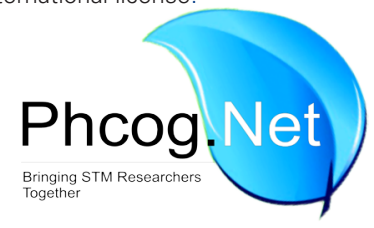

\begin{abstract}
Aim/Background: The objectives of the study were to determine total phenolic contents, flavonoid contents, antioxidant activities and assess acute toxicity of torch ginger (Etlingera elatior Jack.) inflorescent hydroethanolic extract. Methods: The analysis of total phenolic contents, total flavonoid contents and antioxidant activities were analyzed spectrophotometrically using micro-titer plate reader. With regard to acute toxicity assessment, Wistar rats were fed with a single dose of torch-ginger either $1.0,1.5$ or $2.0 \mathrm{~g}$ extract $/ \mathrm{kg}$ body weight in comparison with control group. Results: Total phenolic contents, flavonoid contents of the extract were $0.17 \pm 0.02 \mathrm{mM}$ gallic acid equivalent/g extract and $0.30 \pm 0.01 \mathrm{mM}$ quercetin equivalent/g extract, respectively. The antioxidant evaluation using DPPH radical scavenging assay, FRAP assay and ABTS radical scavenging assay were $0.14 \pm 0.08 \mathrm{mg} / \mathrm{ml}\left(\mathrm{EC}_{50}\right)$, $0.13 \pm 0.01 \mathrm{mmol} \mathrm{Fe}{ }^{2+}$ equivalent $/ \mathrm{g}$ extract and $0.30 \pm 0.12 \mathrm{mM}$ trolox equivalent $/ \mathrm{g}$ extract, respectively. According to acute toxicity, no mortality or bizarre behavior had been observed throughout 14 days. Clinical chemistry including blood glucose, AST, ALT, BUN, creatinine, total cholesterol, triglyceride, HDL, LDL, total serum protein, albumin, globulin and total bilirubin were in normal ranges and comparable to the control $(p<0.05)$. In conclusion, phenolic compounds and flavonoids of torch-ginger could be measured and indicated the quality of the extract as well as antioxidant activities. Regarding acute toxicity assessment, the extract was safe for experimental animals up to $2.0 \mathrm{~g}$ extract $/ \mathrm{kg}$ body weight. Conclusion: Torch-ginger extract exhibited high amounts of phenolic contents, flavonoid contents, antioxidant activities and was safe in animal model.
\end{abstract}

Key words: Torch ginger, Antioxidant activities, Acute toxicity, Total phenolic contents, Total flavonoid contents.

\section{INTRODUCTION}

Plant secondary metabolites, phenolic compounds and flavonoids, are commonly found in plants and possess various pharmacological activities. They are also used as functional foods to prevent cardiovascular disease, dyslipidemia, cancer and diabetes. ${ }^{1}$ Several studies had been evaluated in vitro biological activities of plant extract such as antimicrobial, ${ }^{2}$ antioxidant activities. ${ }^{3-4}$ Long-term oxidative stress contributes to pathogenesis of chronic diseases such as diabetes, chronic kidney disease and some cancer. ${ }^{3}$ There were also clinical efficacy of plant food supplement on diabetes patients. ${ }^{5-6}$

Torch ginger (Etlingera elatior Jack., Family Zingiberaceae) is normally grown in South-east Asia. It was generally used as herb or for cut flower production. ${ }^{7}$ It was also contained enormous phenolic compounds and flavonoids as well as antioxidant properties. ${ }^{8}$ Bioactive compounds from torch ginger can be extracted using various organic solvents; methanol, ethanol, acetone and water. Torch ginger extract was also expressed various pharmacological properties; antioxidant, antimicrobial, antifungal, tyrosinase inhibition, cytotoxic and hepatoprotective activities. ${ }^{9}$ As generally used as food ingredient, toxicity should be evaluated either in rats or other organisms. ${ }^{10}$ In a previous study, methanol extract of torch ginger was assessed in brine shrimps (Artemia salina) and showed no toxicity. In recent study, the aims of this research were to determined phenolic compounds, flavonoid contents, antioxidant activities and acute toxicity of torch ginger inflorescent extract.

\section{MATERIALS AND METHODS}

\section{Plant materials}

Torch ginger (Etlingera elatior Jack.) inflorescences were harvested in October 2013 in Samut Songkhram Province. The authentic sample was identified and collected in the herbarium of the Faculty of Pharmacy, Mahasarakham University, Thailand. The sample was washed with deionized water and cut in small pieces prior to air-dry condition at $50^{\circ} \mathrm{C}$ for $24 \mathrm{~h}$. The sample was then ground and stored in air tight box before extraction. 


\section{Extraction}

The ground sample was extracted by means of ultrasonication. The ratio of solid to liquid ratio of sample to $50 \%$ ethanol was prepared at $1: 50 \mathrm{w} / \mathrm{v}$. Then, the prepared sample was placed into ultrasonic bath (Crest technology, Malaysia). The resultant was filtered and evaporated by rotary evaporator. Then, the sample was dried by lyophilization. The dry hydroexthanolic extract was kept under vacuum and protected from light.

\section{Determination of total phenolic content (TPC)}

Total phenolic content of the extract was analyzed by Folin Ciocâlteu (FC) assay with slight modification from previous studies. ${ }^{11-12}$ The extract of $1 \mathrm{mg} / \mathrm{ml}$ in $80 \%$ ethanol $(25 \mu \mathrm{L})$ was added to $125 \mu \mathrm{L}$ of FC reagent in 96-well microtiter plate and subsequently added $100 \mu \mathrm{L}$ of sodium carbonate $(75 \mathrm{~g} / \mathrm{L})$. The mixture was then incubated for $2 \mathrm{~h}$ at ambient temperature. The absorbance was measured at $760 \mathrm{~nm}$ using microplate reader (Labortech, Germany). Total phenolic content was expressed in $\mathrm{mM}$ gallic acid equivalent per mg of extract (mM GAE/mg extract).

\section{Determination of total flavonoid content (TFC)}

Determination of total flavonoid content was carried out using aluminium chloride method as described previously. ${ }^{13-14}$ Twenty five microliter of the extract (at a concentration of $1 \mathrm{mg} / \mathrm{ml}$ in $80 \%$ ethanol) was added to 96-well microtiter plate and then added $75 \mu \mathrm{L} 95 \%$ ethanol. After that, $5 \mu \mathrm{L}$ of $10 \%$ Aluminium chloride and $5 \mu \mathrm{L}$ of $1 \mathrm{M}$ potassium acetate were added into the solution. Finally, the solution was diluted with $140 \mu \mathrm{L}$ of distilled water and incubated for $30 \mathrm{~min}$ before measurement. The absorbance of the resultant was measured at $415 \mathrm{~nm}$ using spectrophotometer (Labortech, Germany). The extract was calculated in $\mathrm{mM}$ quercetin equivalent per mg of extract (mM QE/mg extract).

\section{DPPH radical scavenging assay}

The effect of extract on reduction of free radical of 2,2-diphenyl-1picrylhydrazyl (DPPH) was determined as previously described with some modification. ${ }^{8}$ The extract was prepared in methanol for 5 concentrations $(15-500 \mu \mathrm{g} / \mathrm{mL})$. The solution of different concentrations $(750 \mu \mathrm{L})$ was added to equal volume of DPPH solution $(60 \mu \mathrm{g} / \mathrm{mL}$ in methanol). The mixture was then thoroughly shaken and left in the dark place at room temperature for $20 \mathrm{~min}$. Subsequently, the absorbance was measured at $517 \mathrm{~nm}$ against methanol. The percentage of radical scavenging was calculated according to the formula:

$$
\text { Percentage }=\frac{A_{c t r}-A_{\text {sample }}}{A_{c t r}} \times 100
$$

Where $\mathrm{A}_{\mathrm{ctr}}$ is the absorbance of control (DPPH solution without extract) and $\mathrm{A}_{\text {sample }}$ is the absorbance of the DPPH solution with extract.

The percentage inhibition was plotted against concentration. Inhibitory concentration at $50 \%$ was calculated from the calibration line.

\section{Ferric ion reducing antioxidant power assay (FRAP assay)}

The antioxidant of extract using reducing power assay was modified from Wijekoon et al. ${ }^{8}$ The FRAP reagent was consisted of $30 \mathrm{~mL}$ of $0.3 \mathrm{M}$ acetate buffer $\mathrm{pH} 3.6,1 \mathrm{~mL}$ of TPTZ solution (10 mM 2,4,6-tris(2pyridyl)-5-triazine in $40 \mathrm{mM} \mathrm{HCl}$ ) and $1 \mathrm{~mL}$ of $20 \mathrm{mM}$ ferric chloride solution. The extract at a concentration of $1 \mathrm{mg} / \mathrm{ml}(100 \mu \mathrm{L})$ was added to $3 \mathrm{~mL}$ of FRAP reagent. The mixture was then mixed and incubated for $10 \mathrm{~min}$ and measured the absorbance at $593 \mathrm{~nm}$. The reducing power was calculated as millimoles of ferrous (II) per mg of extract ( $\mathrm{mM} \mathrm{Fe}^{2+} / \mathrm{mg}$ extract).

\section{2, 2'-azino-bis (3-ethylbenzthiazoline-6-sulphonic acid) assay (ABTS} assay)

The extract at a concentration of $1 \mathrm{mg} / \mathrm{ml}$ (in $80 \%$ Ethanol) was used to assess antioxidant capacity. The ABTS (2, 2'-azino-bis (3-ethylbenzthiazoline-6-sulphonic acid)) solution was mixed in equal volume of $7 \mathrm{mM}$ ABTS and $2.45 \mathrm{mM}$ potassium persulfate. The mixture was left in dark place for $16 \mathrm{~h}$. Then, the resultant was diluted with methanol to obtain the absorbance of 1.00 at $734 \mathrm{~nm}$. In the test method, $150 \mu \mathrm{L}$ was added to $150 \mu \mathrm{L}$ of ABTS solution and subsequently incubated at room temperature for $6 \mathrm{~min}$. The absorbance of the sample was then measured at $734 \mathrm{~nm}$. The antioxidant capacity was expressed as trolox equivalent in $\mu \mathrm{g} / \mathrm{mg}$ extract ( $\mu \mathrm{g}$ TEAC/ mg extract).

\section{Acute toxicity assessment}

Male and female Wistar Rats, six week-old, with weight between 200 - $250 \mathrm{~g}$ were obtained from North East Laboratory Animal Center (Khon Kaen, Thailand) and kept in at the Faculty of Sciences, Mahasarakham University. The rats were left in separate laboratory at $25 \pm 2{ }^{\circ} \mathrm{C}$ with relative humidity of $40-60 \%$ and maintained $12 \mathrm{~h}$ light/dark cycle. The rats were fed with a standard diet from National Laboratory Animal Center (Nakhon Prathom, Thailand), and allowed to access to water ad libitum, and acclimated to laboratory conditions for 7 days. ${ }^{15}$

The experiment rats were divided into 4 groups, one control group and 3 treatment groups. The torch ginger extracts in $0.5 \%$ Tween 80 at concentrations of 1000,1500 and $2000 \mathrm{~g} / \mathrm{kg}$ body weight were fed orally using orogastric feeding device. After single dose administration, the animals were hourly observed for gross behavioral, neurological, autonomic, and toxic effects for $24 \mathrm{~h}$ and then twice daily for 14 days. The clinical signs of toxicity and mortality were investigated including the change in gait, posture, and response to handling and the presence of clonic or tonic movements, or bizarre behavior. At the day 14, blood sample for clinical chemistry tests including serum aspartate aminotransferase (AST), serum alanine aminotransferase (ALT), alkaline phosphatase (ALP), blood urea nitrogen (BUN), blood creatinine, total cholesterol (TC), triglycerides (TG), high density lipoprotein cholesterol (HDL), low density lipoprotein cholesterol (LDL), total serum protein (TP), albumin (ALB), globulin, total bilirubin, and serum glucose were collected directly from aorta under chloroform anesthesia. The weight of inner organs; liver, kidneys, heart and lungs, were assessed comparing with the control group.

Statistical analysis, means and standard deviations of each parameter were calculated and compared among each group, a control and 3 treatment groups. Normality, randomness and homogeneity of variance were evaluated prior to statistical testing (ANOVA, $P$ value $<0.05$ ). Scheffe's test was also performed to compare the difference among groups.

\section{RESULTS AND DISCUSSION}

\section{Determination of phenolic compounds and flavonoids}

Phenolic compounds and flavonoids were determined using spectrophotometric method. Basically, these compounds express high antioxidant according to their hydrogen atom transfer and/or electron donation. ${ }^{16}$ The determination of phenolic compounds and flavonoids of the torch ginger extract was previously studied using water, methanol (100\%, 90\% and $50 \%)$ and acetone $(100 \%, 90 \%$ and $50 \%)$ as extracting solvents. The highest amounts of both compounds were extracted using 50\% of methanol and acetone. ${ }^{8}$ The current study had used $50 \%$ ethanol as extracting solvent due to safety consideration. The polarity of $50 \%$ ethanol is similar to both $50 \%$ methanol and $50 \%$ acetone. The ethanol residue from extraction is less toxicity comparing to methanol or acetone. The amount of phenolic compounds was $0.17 \pm 0.02 \mathrm{mM}$ gallic acid equivalent/mg extract $(n=3)$. In case of flavonoid determination, 
the compounds are commonly chelated with metal ion which initiated lipid peroxidation. Intensity of complexation between flavonoids and aluminium ion indicated the amount of flavonoids, and can be measured spectrophotometrically. Total flavonoids content from the method previously described was $0.30 \pm 0.01 \mathrm{mM}$ quercetin equivalent $/ \mathrm{mg}$ extract $(n=3)$.

\section{Antioxidant activities}

Antioxidant activities were evaluated using DPPH radical scavenging assay, FRAP assay and TEAC assay. The mechanism of DPPH radical scavenging assay is based on hydrogen or electron donating of analytes to DPPH radicals. ${ }^{16-17}$ The antioxidant activity using DPPH radicals is basically related to the intensity reduction of the purple radicals to yellow. The antioxidant activity was exhibited as percentage inhibition of radical comparing with the control. Determination of $\mathrm{IC}_{50}$ of the extract using $50 \%$ ethanol was prepared in two-fold dilution and calculated a regression line over $50 \%$ inhibition. The $\mathrm{IC}_{50}$ using $\mathrm{DPPH}$ radical scavenging assay of the extract was $0.14 \pm 0.08 \mathrm{mg} / \mathrm{mL}(\mathrm{n}=3)$.

For FRAP assay, the reducing power of the extract was determined as the reduction of $\mathrm{Fe}^{3+}$-TPTZ complex to $\mathrm{Fe}^{2+}$-TPTZ in acidic condition. ${ }^{17}$ The intensity of the reduce form can be measured at $593 \mathrm{~nm}$ in comparison with standard curve of $\mathrm{Fe}^{2+}$ in reaction well. FRAP value of the extract was $0.13 \pm 0.01 \mathrm{mM} \mathrm{Fe}{ }^{2+}$ equivalent $/ \mathrm{mg}$ extract $(\mathrm{n}=3)$. In ABTS assay, antioxidant compounds are reacted with ABTS in a present of potassium persulfate and measured at $734 \mathrm{~nm}$ using spectrophotometer. The intensity of the resultant correlated to the amount of antioxidant compounds in the extract. The antioxidant activity was calculated on a basis of intensity of a standard trolox in different concentrations. The trolox equivalent antioxidant capacity of the extract was $0.30 \pm 0.12 \mathrm{mM}$ trolox equivalent $/ \mathrm{mg}$ extract $(n=3)$. Summary of total phenolic contents, flavonoid contents and antioxidant activities were shown in Table 1.
Table 1: Total phenolic contents, flavonoid contents and antioxidant activity of torch ginger extract $(n=3)$.

\begin{tabular}{|c|c|c|c|c|c|}
\hline & $\begin{array}{c}\text { TPC } \\
\text { (mM } \\
\text { GAE/mg } \\
\text { extract) }\end{array}$ & $\begin{array}{c}\text { TFC } \\
\text { (mM } \\
\mathrm{QE} / \mathrm{mg} \\
\text { extract) }\end{array}$ & $\begin{array}{c}\text { DPPH } \\
\text { assay } \\
\left(\mathrm{IC}_{50^{\prime}} \mathrm{mg} /\right. \\
\mathrm{mL})\end{array}$ & $\begin{array}{c}\text { FRAP } \\
\text { assay } \\
\text { (mM } \\
\mathrm{Fe}^{2+} / \mathrm{mg} \\
\text { extract) }\end{array}$ & $\begin{array}{c}\text { ABTS } \\
\text { assay } \\
\text { (TEAC/ mg } \\
\text { extract) }\end{array}$ \\
\hline extract & $0.17 \pm 0.02$ & $0.30 \pm 0.01$ & $0.14 \pm 0.08$ & $0.13 \pm 0.01$ & $0.30 \pm 0.12$ \\
\hline
\end{tabular}

\section{Acute toxicity}

Acute toxicity of torch ginger extract was evaluated in Wistar rats. The treatment groups were orally administered at concentration of 1000,1500 and $2000 \mathrm{mg} / \mathrm{kg}$ body weight diluted with $0.5 \%$ Tween 80 . The control group was fed with $0.5 \%$ Tween 80 without any additives. Survival and clinical observation after oral administration had been monitored hourly for $24 \mathrm{~h}$. There was neither mortality nor abnormal clinical signs including scrubbing, unusual defecation or urination, vocalization on handling and bizarre behavior in the first day. After that, the mortality and clinical signs had been observed twice daily for 14 days. There was no mortality and abnormal clinical signs as well. At the end of day 14, blood samples were collected for clinical chemistry test. Clinical chemistry parameters; AST, ALT), ALP, BUN, blood creatinine, TC, TG, HDL, LDL, TP, ALB, globulin, total bilirubin and serum glucose of the treatment groups were not significant differences from the control group except alkaline phosphatase from $1000 \mathrm{mg}$ extract $/ \mathrm{kg}$ body weight treated group ( $p$ value $\geq 0.05$ ) as shown in Table 2 . Inner organs including liver, kidneys, heart and lungs were also weighed immediately after dissection to avoid dryness. ${ }^{10}$ The weight of the organs from treatment groups were not significant differences comparing with the control group ( $p$ value $\geq 0.05$ )

Table 2: Effect of torch ginger extract on clinical chemistry parameters in Wistar rats.

\begin{tabular}{ccccc}
\hline parameters & control & $\begin{array}{c}1000 \mathrm{mg} / \mathrm{kg} \text { body } \\
\text { weight }\end{array}$ & $\begin{array}{c}\text { ext1500 mg/kg } \\
\text { body weight }\end{array}$ & $\begin{array}{c}\text { ext2000 mg/kg } \\
\text { body weight }\end{array}$ \\
\hline Glucose $(\mathrm{mg} / \mathrm{dl})$ & $146.60 \pm 8.15^{\mathrm{a}}$ & $141.33 \pm 13.17^{\mathrm{a}}$ & $140.00 \pm 11.68^{\mathrm{a}}$ & $157.33 \pm 9.32^{\mathrm{a}}$ \\
BUN(mg/dl) & $26.48 \pm 1.58^{\mathrm{a}}$ & $28.06 \pm 1.98^{\mathrm{a}}$ & $28.80 \pm 1.59^{\mathrm{a}}$ & $27.75 \pm 1.36^{\mathrm{a}}$ \\
Creatinine(mg/dl) & $0.84 \pm 0.02^{\mathrm{a}}$ & $0.85 \pm 0.03^{\mathrm{a}}$ & $0.91 \pm 0.03^{\mathrm{a}}$ & $0.95 \pm 0.02^{\mathrm{a}}$ \\
Uric(mg/dl) & $3.72 \pm 0.28^{\mathrm{a}}$ & $3.81 \pm 0.36^{\mathrm{a}}$ & $4.75 \pm 0.49^{\mathrm{a}}$ & $3.36 \pm 0.23^{\mathrm{a}}$ \\
Cholesterol(mg/dl) & $78.00 \pm 5.95^{\mathrm{a}}$ & $73.66 \pm 5.37^{\mathrm{a}}$ & $73.16 \pm 5.12^{\mathrm{a}}$ & $73.16 \pm 5.38^{\mathrm{a}}$ \\
TG(mg/dl) & $123.60 \pm 13.41^{\mathrm{a}}$ & $120.83 \pm 8.59^{\mathrm{a}}$ & $122.16 \pm 8.69^{\mathrm{a}}$ & $117.33 \pm 15.95^{\mathrm{a}}$ \\
HDL(mg/dl) & $16.60 \pm 1.12^{\mathrm{a}}$ & $15.33 \pm 0.84^{\mathrm{a}}$ & $15.50 \pm 1.23^{\mathrm{a}}$ & $15.83 \pm 1.04^{\mathrm{a}}$ \\
LDL(mg/dl) & $38.00 \pm 5.31^{\mathrm{a}}$ & $37.16 \pm 2.99^{\mathrm{a}}$ & $38.83 \pm 2.24^{\mathrm{a}}$ & $37.00 \pm 3.17^{\mathrm{a}}$ \\
Total protein(mg/dl) & $6.06 \pm 0.12^{\mathrm{a}}$ & $5.83 \pm 0.17^{\mathrm{a}}$ & $6.11 \pm 0.12^{\mathrm{a}}$ & $5.76 \pm 0.05^{\mathrm{a}}$ \\
Albumin(g/dl) & $3.86 \pm 0.06^{\mathrm{a}}$ & $3.76 \pm 0.06^{\mathrm{a}}$ & $3.90 \pm 0.08^{\mathrm{a}}$ & $3.75 \pm 0.02^{\mathrm{a}}$ \\
Globulin(g/dl) & $2.20 \pm 0.07^{\mathrm{a}}$ & $2.06 \pm 0.11^{\mathrm{a}}$ & $2.21 \pm 0.07^{\mathrm{a}}$ & $2.01 \pm 0.04^{\mathrm{a}}$ \\
Total bilirubin(mg/dl) & $0.30 \pm 0.03^{\mathrm{a}}$ & $0.38 \pm 0.08^{\mathrm{a}}$ & $0.38 \pm 0.08^{\mathrm{a}}$ & $0.26 \pm 0.03^{\mathrm{a}}$ \\
AST(U/L) & $78.60 \pm 2.60^{\mathrm{a}}$ & $131.00 \pm 25.66^{\mathrm{a}}$ & $106.16 \pm 14.62^{\mathrm{a}}$ & $77.50 \pm 3.14^{\mathrm{a}}$ \\
ALT(U/L) & $29.20 \pm 0.96^{\mathrm{a}}$ & $32.66 \pm 2.80^{\mathrm{a}}$ & $41.00 \pm 7.67^{\mathrm{a}}$ & $28.00 \pm 1.61^{\mathrm{a}}$ \\
ALP(U/L) & $100.60 \pm 4.10^{\mathrm{a}}$ & $142.00 \pm 13.80^{\mathrm{b}}$ & $113.16 \pm 8.05^{\mathrm{ab}}$ & $110.50 \pm 5.84^{\mathrm{ab}}$ \\
\hline
\end{tabular}

Statistical testing was evaluated using ANOVA. Scheffe's test was also performed to compare the difference among groups.

a, b different alphabet indicated statistical significance $(P$ value $<0.05)$. 
Table 3: Effect of torch ginger extracts on the weight (gram) of inner organs.

\begin{tabular}{ccccc}
\hline organ & control & $\begin{array}{c}1000 \mathrm{mg} / \mathrm{kg} \\
\text { body weight }\end{array}$ & $\begin{array}{c}\text { ext1500 } \\
\text { body weight }\end{array}$ & $\begin{array}{c}\text { ext2000mg/kg } \\
\text { body weight }\end{array}$ \\
\hline Liver & $4.84 \pm 0.31^{\mathrm{a}}$ & $4.99 \pm 0.38^{\mathrm{a}}$ & $5.13 \pm 0.38^{\mathrm{a}}$ & $5.13 \pm 0.60^{\mathrm{a}}$ \\
Kidneys & $0.76 \pm 0.04^{\mathrm{a}}$ & $0.85 \pm 0.04^{\mathrm{a}}$ & $0.07 \pm 0.03^{\mathrm{a}}$ & $0.89 \pm 0.06^{\mathrm{a}}$ \\
Heart & $0.44 \pm 0.02^{\mathrm{a}}$ & $0.41 \pm 0.01^{\mathrm{a}}$ & $0.42 \pm 0.02^{\mathrm{a}}$ & $0.42 \pm 0.02^{\mathrm{a}}$ \\
Lungs & $0.58 \pm 0.04^{\mathrm{a}}$ & $0.61 \pm 0.02^{\mathrm{a}}$ & $0.59 \pm 0.02^{\mathrm{a}}$ & $0.71 \pm 0.09^{\mathrm{a}}$ \\
\hline
\end{tabular}

Statistical testing was evaluated using ANOVA. Scheffe's test was also performed to compare the difference among groups.

${ }^{\mathrm{a}, \mathrm{b}}$ different alphabet indicated statistical significance $(P$ value $<0.05)$.

as shown in Table 3. According to the dose of the extract, the acute toxicity test was performed up to $2000 \mathrm{mg}$ extract/kg body weight which was relatively high. The results revealed that there was no evidences of mortality, abnormal clinical signs or bizarre behavior found during the experiment. Therefore, we decided to stop increasing the dose of extract for acute toxicity test.

\section{CONCLUSION}

Torch ginger inflorescent extract exhibited in high phenolic and flavonoid contents. Their antioxidant activities was also expressed in high capacity in the test models. According to acute toxicity test using Wistar rat, oral administration of the extract was safe up to $2000 \mathrm{mg} / \mathrm{kg}$ body weight. The extract is beneficial for further development of food supplementation product for antioxidant purposes.

\section{ACKNOWLEDGEMENT}

The authors would like to thanks the Thailand Research Fund, grant No. RDG5650116 for financial support, and Mahasarakham University Development Fund for facilities.

\section{CONFLICT OF INTEREST}

The authors declare no conflict of interest.

\section{ABBREVIATIONS}

IC $_{50}$ : The concentration required to reduce by $50 \%$ response; AST: Serum aspartate aminotransferase; ALT: Serum alanine aminotransferase; ALP: Alkaline phosphatase; BUN: Blood urea nitrogen; TC: Total cholesterol; TG: Triglycerides; HDL: High density lipoprotein cholesterol;
LDL: Low density lipoprotein cholesterol; TP: Total serum protein; ALB: albumin.

\section{REFERENCES}

1. Devi S, Singh R. Antioxidant and Anti-hypercholesterolemic potential of Vitis vinifera leaves. Pharmacog J. 2017;9(6):807-14.

2. Chan EWC, Ng VP, Tan VV, Low YY. Antioxidant and antibacterial properties of Alpinia galanga, Curcuma longa, and Etlingera elatior (Zingiberaceae). Pharmacog J. 2011a;3(22):54-61.

3. Lee YM, Yoon H, Park HM, Song BC, Yeum KJ. Implications of red Panax ginseng in oxidative stress associated chronic diseases. J Ginseng Res. 2017;41(2):113-9.

4. Sulaiman SF, Sajak AAB, Ooi KL. Supriatno, Seow EM. Effect of solvents in extracting polyphenols and antioxidants of selected raw vegetables. J Food Comp Anal. 2011;24(4-5):506-15.

5. Riche DM, Riche KD, East HE, Barrett EK, May WL. Impact of mulberry leaf extract on type 2 diabetes (Mul-DM): A randomized, placebo-controlled pilot study. Complement Ther Med. 2017;32:105-8.

6. Zare R, Nadjarzadeh A, Zarshenas MM, Shams M, Heydari M. Efficacy of cinnamon in patients with type II diabetes mellitus: A randomized controlled clinical trial. Clin Nutr. 2018; in press doi: 10.1016/j.clnu.2018.03.003.

7. Yunus MF, Aziz MA, Kadir MA, Rashid AA. In vitro propagation of Etlingera elatior (Jack) (torch ginger). Sci Hort. 2012;135:145-50.

8. Wijekoon MMJ, Bhat R, Karim AA. Effect of extraction solvents on the phenolic compounds and antioxidant activities of bunga kantan (Etlingera elatior Jack.) inflorescence. J Food Comp Anal. 2011;24(4-5):615-9.

9. Chan EWC, Lim YY, Wong SK. Phytochemistry and pharmacological properties of Elingera elatior. A review. Phcog J. 2011b;3(22):6-10.

10. Yuan GP, Dai SJ, Yin ZQ, Lu HK, Jia RY, Xu J, et al. Toxicological assessment of combined lead and cadmium: Acute and sub-chronic toxicity study in rats. Food Chem Toxicol. 2014;65:260-8.

11. Rattana S, Katisart T, Sungthong B, Butiman C. Acute and Sub-acute Toxicities of Thai Silkworm Powder (Bombyx mori Linn.) From Three Races in Male Wistar Rats and In vitro Antioxidant Activities. Pharmacog J. 2017;9(4):541-5.

12. Sato VH, Sungthong B, Rinthong P, Nuamnaichati N, Mangmool S, Chewchida S, et al. Pharmacological effects of Chatuphalatika in hyperuricemia of gout. Pharm Biol. 2018;56(1):76-85.

13. Do QD, Angkawijaya AE, Tran-Nguyen PL, Huynh LH, Soetaredjo FE, Ismadji S, et al. Effect of extraction solvent on total phenol content, total flavonoid content, and antioxidant activity of Limnophila aromatica. J Food Drug Anal. 2014;22(3):296-302

14. Pandey G, Khatoon S, Pandey MM, Rawat AKS. Altitudinal variation of berberine, total phenolics and flavonoid content in Thalictrum foliolosum and their correlation with antimicrobial and antioxidant activities. J Ayurveda Integr Med. 2017; pii: S0975-9476(16)30443-0.

15. Chaimum-aom N, Chomko S, Talubmook C. Toxicology and oral glucose tolerance test (OGTT) of Thai medicinal plant used for diabetes control, Phyllanthus acidus L. (EUPHORBIACEAE). Pharmacog J. 2017;9(1):58-61.

16. Bajpai VK, Alam MB, Ju MK, Kwon KR, Huh YS, Han YK, et al. Antioxidant mechanism of polyphenol-rich Nymphaea nouchali leaf extract protecting DNA damage and attenuating oxidative stress-induced cell death via Nrf2-mediated heme-oxygenase-1 induction coupled with ERK/p38 signaling pathway. Biomed Pharmacother. 2018;103:1397-407.

17. Moon J, Shibamoto T. Antioxidant assays for plants and food components J Agri Food Chem. 2009;57(5):1655-66.

\section{GRAPHICAL ABSTRACT}

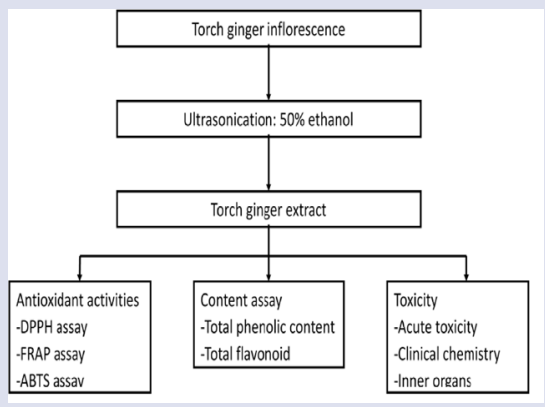

\section{SUMMARY}

- The present research provides information about total phenolic contents, flavonoid contents, antioxidant activities and acute toxicity of torch-ginger (Etlingera elatior Jack.) inflorescent hydroethanolic extract.

Cite this article: Sungthong B, Srichaikul B. Antioxidant Activities, Acute Toxicity and Chemical Profiling of Torch Ginger (Etlingera elatior Jack.) Inflorescent Extract. Pharmacog J. 2018;10(5):979-82. 